21

\title{
Land acquisition induced conflicts in suburban China: A procedural perspective
}

\section{Introduction: Land acquisition conflicts and a procedural perspective}

In China, local governments are highly incentivised to convert rural land for urban uses (Tang et al., 2016, Wang et al., 2016, Wang \& Hui, 2017), in the context of land market establishment (Lin \& Zhang, 2014, Ong, 2014, Wen et al., 2017). Vast swathes of farmland in urban fringe areas have thus been acquired for urban construction and development (Hui et al., 2015, Li et al., 2017, Shen \& Wu, 2016). Consequently, China's agricultural land has significantly decreased in area (Ministry of Land and Resources of the People's Republic of China, 2017), which causes food insecurity in the country (Yang \& Li, 2000). Landless rural households appear to be the group most affected by land acquisition (Song et al., 2016, Zhu $\&$ Prosterman, 2007). The lack of legal certainty over rural China's collective land ownership, in which individual farmers retain land use right only (Hui \& Bao, 2013), makes landless farmers less powerful in the process (Liu \& Liang, 2015). For example, inequality exists in both inter-group and intra-group interests' distributions (Li et al., 2006). Local governments control many rights, among them development, living, and security rights over land (Li et al., 2015). In addition, landless households' livelihoods have significantly deteriorated as a result of land acquisition (Li et al., 2018). Therefore, the issue has become one of the most prominent conflicts in rural China (Shan et al., 2017, Zhou et al., 2017), and significantly threatens the country's social and political stability (Cao et al., 2008).

Academic studies have drawn much attention to these conflicts in land acquisition in China. For example, Rooij (2007) discussed conflicts that resulted from land acquisition by focusing on the weak land tenure security in peri-urban Kunming. By tracing the flow of profit distribution from land acquisition in a suburban village in Shandong province, Song et al. (2016) found that extensive protests among villagers are triggered by allegedly corrupt conduct by the village secretary that is apparently supported by the local government. However, studies that aim to interpret the procedural aspects of land acquisition induced conflicts are lacking. In particular, conflicts induced by land acquisition activities in China have not been studied by comparing the differences between official land acquisition procedures and their implementation in real situations. This comparison is important: as

This is the author manuscript accepted for publication and has undergone full peer review but has not been through the copyediting, typesetting, pagination and proofreading process, which may lead to differences between this version and the Version of Record. Please cite this article as doi: 10.1111/1745-5871.12343

This article is protected by copyright. All rights reserved. 
Matland (1995) notes when describing his ambiguity-conflict model, the blurred boundary between official and actual procedures and policies could produce conflicts. The ambiguityconflict model provides an alternative approach to top-down and bottom-up methods to understand policy implementation and accounts for the tendency among local officials to interpret central policy in ways that enable them to control available resources and try to deal with conflict. In the Chinese context, where land revenue has become a large proportion of local wealth accumulation (Ding, 2007), local officials selectively implement policies to achieve their own demands. A pattern of selective policy implementation is therefore emerging in China and has already been shown in a landmark study by O'Brien and Li (1999). Clearly, appropriate land acquisition procedures are important to minimise any social, economic, psychological, and ecological impacts to society (Asif, 1999). Hence, for the sake of procedural equality, there is need to address how conflicts are triggered by the mismatch between de jure and de facto procedures in land acquisition in China.

This study develops an approach to a procedural perspective on land acquisition in China to better understand the nature of conflicts arising from land acquisition. We ask: What is the de facto land acquisition procedure in China? What procedures were carried out by the local officials? What are the differences between de facto and de jure procedures? How did conflicts arise during the land acquisition process? Addressing these questions, we expect to unravel certain complexities and tensions involved in the politics of land acquisition. We argue that the discrepancies between de facto and de jure processes of land acquisition explain much of the conflict over land acquisition and compensation in China.

The next section introduces the methodology of this research. We conducted empirical first-hand research and an in-depth case study of the land acquisition process in a village in urban fringe area in China. Data were collected from interviews and land acquisition policies and regulations established at various levels of government. Section 3 introduces the de jure procedure of land acquisition in China. Section 4 and Section 5 explain the de facto land acquisition procedures for farmland and residential land respectively in the case study. Section 6 discusses the key findings of this research and provides policy implications from this study. 


\section{Methodology}

This study is based on a real land confiscation case in an urban fringe area, Village $C$, in Jining city, Shandong province, China. Village C was selected for two reasons. First, the village is a typical conflict case, being one of a dozen such suburban villages in Jining city that have been targeted region for Jining's urban expansion. Conflicts associated with land acquisition in this city have been reported by Chinese media. Second, given the restrictions imposed by local officials on information about land acquisition, Village $\mathrm{C}$ was chosen because the researchers had access to key informants. These local contacts included ordinary farmers, the village head, other representatives elected by the villagers, and campaign leaders against the land acquisition, all of whom could offer insights rare in the literature.

After ethics clearances were secured by us, field work for the research was conducted in November 2013 and during the 2015 Chinese New Year. During these field trips, we collected 79 household surveys and dozens of interviews, including semi-structured interviews with 15 villagers, one village committee member, and two local representatives who led local to protect against land acquisition corruption. We collected information about both de jure and de facto procedures and interviewed peasants about what actually took place in relation to land acquisition. We analysed a range of documents such as announcements and regulations released by the district government and village committee; and official documents such as laws, regulations, and policies established by the central, provincial, municipal, and district level governments that summarised the de jure land acquisition procedure. The following sub-sections describe our findings. We then compare the de jure procedures with the de facto procedures to identify the disparities between the two processes.

\section{De jure procedure for land acquisition in China}

Based on the analysis of primary and secondary data collected for this study, Figure 1 outlines China's statutory land acquisition procedures as stipulated in central government 
policies, laws, and local government documents. ${ }^{1}$ The following sections explain the various stages of the process that underpins this element of procedure.

[Insert Figure 1 here].

\section{The planning stage}

In China, two government plans are relevant to land acquisition: the Five-Year Plan and Land Use Master Plan (LUMP). The Five-Year Plan is a comprehensive development plan that determines economic growth rates, industrial modulation direction, and people's livelihood and environmental enhancement over a five-year period (National Development and Reform Committee, 2016). With a planning period of 15 to 20 years, LUMP arranges the general use, exploitation, reclamation, and protection of all land within a given jurisdiction (The Central People's Government of the People's Republic of China, 2008). The LUMP controls the spatial setting and land demand that is driven by the Five-Year Plan, and the Five-Year Plan in turn influences the composition of LUMP. The Annual Plan for City Land Use (APCLU) is the concrete annual arrangement of the amount of transferable farmland, consolidation and replenishment land, and farmland possessed at a city level (Ministry of Land and Resources of the People's Republic of China, 2015). The APCLU complies with the LUMP to restrain the amount of construction land available and protect farmland. The APCLU involves land acquisition, and hence the Land Acquisition Scheme (LAS) needs to be established and sent to upper-level governments along with APCLU.

\section{The compensation method design stage}

Two official procedures exist in this stage (Figure 1). Box A depicts the Improving Institution of Compensation and Relocation for Land Acquisition (IICRLA) (Ministry of Land and Resources of the People's Republic of China, 2005a), and Box B explores the Announcement

\footnotetext{
${ }^{1}$ The Jining City Land Use Master Plan (2006-2020) (Jining Municipal Bureau of Land and Resources, 2014) and the Jining City Master Plan (2008-2030) (Jining Urban and Rural Planning Bureau, 2012).
} 
Method of Land Acquisition (AMLA) (Ministry of Land and Resources of the People's Republic of China, 2015).

Box A. Before presenting the APCLU and LAS to upper-level governments, a local land bureau should, in writing, inform rural collectives and households of the purposes, monetary compensation standards, and relocation methods of land acquisition. It also should confirm with villagers the amount, type, and ownership of the land and its attachments, and notify rural collectives and householders of the right to apply for a public hearing on land acquisition. Villagers who require a public hearing then ask the hearing agency to hold such a meeting within five days after the notification (Ministry of Land and Resources of the People's Republic of China, 2003), otherwise the right is considered waived. If a public hearing is held, any previous LAS should be modified accordingly. If villagers have no further dissatisfaction with monetary compensation standards and relocation methods, the APCLU and LAS permit the case to be sent to upper-level governments (Ministry of Land and Resources of the People's Republic of China, 2006).

Box B. Compared with the process outlined in Box A, here the AMLA sets detailed but significantly different procedures (Ministry of Land and Resources of the People's Republic of China, 2015). In AMLA, the first step is to apply the APCLU and LAS. Local governments are directed to publish any notice of land acquisition within ten days after receiving the permission. The notice includes the following items: (a) permission agency, time, purpose, permission number; (b) the right holders, location, type, and areal extent of the acquired land; (c) monetary compensation standards and relocation method; and (d) time and place for registration.

Rural collectives, villagers, and other land rights holders register for compensation in a designated place before the designated deadline using a land ownership certificate. If they do not register in time, compensation is identified solely by referring to the local land bureau's measurements. If a local government does not publish the notice, rural collectives, villagers, or other land right holders have the right to require notification and refuse registration.

Afterwards, the local government draws up the compensation standards for each land right holder according to the LAS and then inform the villagers. If rural collectives, villagers, or other land right holders have different opinions about the monetary compensation standard 
and/or relocation method, or ask for a public hearing, the relevant land department within the local government is informed within ten days after the notice. The department then reviews the opinions and holds a public hearing. If the monetary compensation standard and relocation scheme needs to be changed, it is modified according to related laws and LAS. Opinions from rural collectives, villagers or other land right holders, and transcripts from public hearings are then sent to the local government along with the monetary compensation standard and relocation method.

\section{The land acquisition stage}

Continuing from the last stage in the AMLA (Ministry of Land and Resources of the People's Republic of China, 2015), the relevant land bureau in a local government implements the monetary compensation and relocation method after the APCLU and LAS get approved. It is within the local government's authority to hand out compensation money to the rural collective and ask the rural collective to report back on the payment of the money.

The IICRLA then directs how to distribute the compensation funds in a given rural collective (Ministry of Land and Resources of the People's Republic of China, 2005a). The money should be allocated reasonably and primarily for use by householders who have lost land in the acquisition process. If all village land is acquired, the rural organisation will cease to exist. In such cases, the entirety of the land compensation should be used for villagers' relocation and livelihood restoration. Meanwhile, related land bureaus can supervise how rural collectives use compensation funds and collaborate with agricultural and civil departments to supervise the allocation and usage of the money for compensation inside rural collectives. Conflicts that arise during these processes are mediated by the affected local government: if they cannot be resolved, upper-level governments then have the authority to deliver a resolution.

\section{The post land acquisition stage}

According to the Decision Concerning Deepening the Reform of Strict Land Management (DCDRSLM) (The Central People's Government of the People's Republic of China, 2004), if money for land acquisition compensation has reached the legal maximum and still does not 
guarantee villagers' previous living standards, the relevant local government should use the income from renting the acquired land to subsidise the villagers (Ministry of Land and Resources of the People's Republic of China, 2004). Land bureaus at all levels should then supervise and examine the implementation of the LAS, and the DCDRSLM emphasises that local land bureaus should work with other departments to secure the villagers' living standard and maintain social stability (Ministry of Land and Resources of the People's Republic of China, 2004).

Item 37 in the Land Administration Law indicates that no company or individual is permitted to leave farmland unused (Ministry of land and Resources of the People's Republic of China, 2005b). Thus, any acquired farmland that has been left unused for one year or less should be recultivated by the original rural collective or company which had used the land. If the acquired farmland has been left unused for more than a year, a fee for wasting farmland is then levied according to regulation. If the acquired farmland has been left unused for two consecutive years, the local government withdraws the land use rights without a fee, but with the permission of the original government that permitted the acquisition, and the farmland is returned to the original rural collective for farming use (Ministry of land and Resources of the People's Republic of China, 2005b). In addition, DCDRSLM supplements stipulate that if the acquired land is not supplied for use, the next year quota of farmland transference will be cut (Ministry of Land and Resources of the People's Republic of China, 2004).

\section{De facto land acquisition procedure: farmland}

The de facto land acquisition procedure in Village $\mathrm{C}$ is different from the official procedure stated above. On that understanding, this section first considers the actual processes of farmland acquisition, Table 1 below summarising the major differences from Figure 1.

[Insert Table 1 here]

\section{Planning and compensation method design stages}

In Village $\mathrm{C}$, residents only obtained information about land acquisition from the village committee when land was levelled by bulldozers. According to our interviews, the village 
committee informed villagers that it possessed official documents for land acquisition but those had never been seen by villagers. It appears that all the official procedures were ignored by both the relevant government agencies and the village committee but should have been conducted in conjunction with villagers in these two stages.

Before land is acquired, officials engage in measurements related to its productivity for twelve months, and compensation for farmland and crops is normally determined by these measurements, but in this case the results had not been confirmed with the villagers. Nor had they been informed about which items would be subject to compensation; about what standards would apply; and about whether measurements were verifiably accurate. Most of the villagers thought that the compensation was far too low. Many also realised that some families, with the same area of land and similar plants, had actually been compensated substantially more. Despite the procedures laid out in Box A or Box B, villagers did not receive any written information of the land acquisition and were not told that they have the right to express opinions or demand a public hearing.

\section{Land acquisition stage}

A number of inconsistencies and departures from official procedure can be identified at this stage. First, the money to be used for compensation was given to the village committee and no information about the funds was provided to villagers. Second, the official procedures require that compensation be paid, and villagers be relocated before the acquisition of farmland. However, in Village $\mathrm{C}$, villagers were relocated after the acquisition. Indeed, when the villagers were told that their farmlands had been sold, they had only a week to harvest their remaining $500 \mathrm{mu}$ (about 333,300 $\mathrm{m}^{2}$ ) of wheat. The land on which it grew was to be levelled immediately and not after the harvest, which would result in serious food waste and financial loss. In order to keep villagers away from the acquired farmland, the local government sent hundreds of cars, working staff, and armed police to ensure the land acquisition process went smoothly. Villagers had neither the right or the opportunity to postpone the process or voice their opinions.

In accordance with procedure, villagers were given compensation for crops on the farmland. However, the calculations used to determine compensation were not revealed, and 
most of the villagers were not satisfied with the amount. According to a Reply from Shandong Provincial Price Bureau and Financial Department Regarding Modulating Compensation Standard of Annual Production and Attachments for Acquiring Land (Shandong Province Finance Bureau, 2015), the compensation for the forest land with mature trees should be 50,000 yuan/mu (about AU $\$ 15 / \mathrm{m}^{2}$ ), but villagers were only given 10,000 yuan/mu (about AU $\$ 3 / \mathrm{m}^{2}$ ). Our interviews established that only a few householders reported receiving fair compensation for their plants, and those were mostly village officials or their relatives. Because all the farmland was levelled, villagers had no evidence to support any complaints about the low compensation.

Normally, compensation for farmland itself is paid to villagers, but that was not done in this case. When we asked the villagers about the deviation from procedure, they said that the village secretary told them that the money would be used for public affairs and would not be paid to villagers. Village representatives then appealed to the local government whose official responsibility it is to resolve such conflicts. In this case, villagers also told us that the local government responded to the representatives' requests with threats and intimidation and arrested several of the representatives.

According to the villagers we interviewed, the only good outcome from the procedure was that every household obtained 200,000 yuan (about AU\$40,000) as compensation for land at the price of 42,000 yuan $/ \mathrm{mu}$ (about AU\$12.60/ $\mathrm{m}^{2}$ ). During the study, neither additional compensation nor support for relocation were offered, and those villagers who had been arrested and/or imprisoned received no more compensation.

\section{After the land acquisition stage}

Based on information from the administered questionnaires and interviews conducted, in Village $\mathrm{C}$ three major aspects of villagers' living standards were affected by the events and procedural deviations outlined above. First and in terms of annual income, compared with the period prior to land acquisition each household lost, on average, 8,165 yuan (about AU\$1,633) Second, annual post-acquisition expenses for each household increased by 10,551 yuan per year (about AU\$2,110), 80 per cent of which was due to the increased cost of food that, alongside crops for sale, had been sourced from the land prior to its being sold. Each 
household's average yearly saving was 20,000 yuan (about AU\$4,000) less than before the land's acquisition. Third, many households lost agricultural and allied jobs in the acquisition. However, the cumulative effects of these three effects and the deteriorated living standards they engendered attracted no attention from any level of government and most villagers' lives appear to have drastically worsened.

In order that the Chinese government can protect acquired farmland, the official procedures stipulate that such farmland should be recultivated if it is acquired but unused (Ministry of land and Resources of the People's Republic of China, 2005b). However, in this case, more than $200 \mathrm{mu}$ of acquired land was left unused for seven years, and both the local government and village secretary deployed trucks and covered the land with rubbish to prevent villagers reusing the land.

\section{De facto land acquisition procedure: residential land}

In Village $\mathrm{C}$, the process of acquisition of residential land and the houses attached to it is more problematic than that used to acquire farmland. Table 2 summarises what procedures were omitted or modified when peasants' residential lands and houses were acquired.

\section{[Insert Table 2 here]}

For residential land acquisition in Village $\mathrm{C}$, villagers were notified about the acquisition eight days before implementation. In June 2008, each household received the Scheme of Demolition Compensation and Relocation Implementation in Village C. The scheme informed villagers that they were to move out their houses within 26 days. Those doing so would be given an extra $20 \mathrm{~m}^{2}$ of area in a new apartment provided as compensation to make a total area of $220 \mathrm{~m}^{2}$, otherwise $200 \mathrm{~m}^{2}$. Resettlement apartments were said to be ready for use 18 months hence.

Although villagers were not satisfied with the compensation, they complied with the standard because they feared punishment and did not want to miss out on extra apartment space. Our survey data show that, on average, ordinary households received two apartments; however, some families who have close relationships with the party secretary reportedly 
received six to seven apartments, and the party secretary received 40 apartments. This outcome suggests a significantly unjust distribution of compensation in Village C.

The results of measurements pertaining to residential land and attached houses were confirmed with the villagers, but the measurements and compensation seem not to have been properly implemented before the actual land acquisition, which is required by the official procedure. The scheme also provides a rent of 5 yuan $/ \mathrm{month} / \mathrm{m}^{2}$ (about AU $\$ 1 / \mathrm{month} / \mathrm{m}^{2}$ ) for each household multiplied by the area of new apartments before householders move into them. Rent would be paid yearly and if the new flats were not ready in 18 months, the rent would be doubled. Although the villagers were promised they could move into their new apartments within 18 months, the process took six years. The villagers rented other apartments during this period.

Households were paid 13,200 yuan (about AU\$2,640 or AU $\$ 1 / \mathrm{month} / \mathrm{m}^{2}$ multiplied by 12 months and then multiplied by the $220 \mathrm{~m}^{2}$ new apartment's area) for annual rent compensation in the first 18 months, and $7.5 \mathrm{yuan} / \mathrm{month} / \mathrm{m}^{2}$ (about AU $\$ 1.5 / \mathrm{month} / \mathrm{m}^{2}$ ) after the 18 months. Villagers were promised a double rent compensation of 10 yuan $/ \mathrm{month} / \mathrm{m}^{2}$ (about AU $\$ 2 / \mathrm{month} / \mathrm{m}^{2}$ ) as mentioned above. However, the rent compensation should actually be 12 yuan $/ \mathrm{month} / \mathrm{m}^{2}$ (about AU $\$ 2.4 / \mathrm{month} / \mathrm{m}^{2}$ ) according to one Jining municipal government document, Advice on Enhancing Management of Urban Housing Demolition (Jining Municipal Government, 2009).

\section{Discussion and conclusion}

Deviations from standard farmland and residential land acquisition procedures in our case study village raise several broader issues explored below.

\section{Coercive public interest}

China's de jure land acquisition procedures define land acquisition as being in the public interest. This case study clearly demonstrates instead the ways in which the rights of farmers had been denied using de facto procedures.

As introduced by the IICRLA, any attachments built or located on land that is then acquired will not be compensated after villagers are informed of a land acquisition (Ministry 
of Land and Resources of the People's Republic of China, 2005a). This notice is usually circulated half a year before villagers' consent to acquisition and before upper-level governments' approval, which means that in order to pursue the so-called public interest, villagers have to give up their land profits and own interests first—despite not being sure if their land will be acquired or not.

As a result of such coercive actions, land acquisition in Village $\mathrm{C}$ was carried out without consideration of the villagers' rights. Acquisition massively increased the local government's own interests and benefits, including in the form of a new luxury local government building on the acquired land, even though the existing government building seemed fit-for-purpose. In short, the acquisition process was used to expropriate villagers' land under the guise of public interest and resulted in their experiencing greatly deteriorated living standards. 


\section{Ambiguous policies}

The de jure land acquisition procedures shown in Boxes A and B illustrate the point that those processes listed in Box B require upper-level governments' approval for the APCLU and LAS first, while those listed in Box A first involve informing villagers of the land acquisition and compensation standard. Procedures listed in Box A include requirements to confirm land information with villagers before sending the APCLU, LAS to the upper-level governments for approvals. Obviously, procedures in Box A are more respectful of villagers' rights. However, in the case of Village C, a notification released by the State Council in 2006 did not actually specify whether a document proving that villagers have been informed of the APCLU and LAS is strictly necessary. The notification in question is known as Regarding Modulating the Examination Process of Urban Construction Land Approved by the State Council (Ministry of Land and Resources of the People's Republic of China, 2006).

Similarly, there are no clear rules about the sequence of monetary compensation, relocation, and actual land acquisition. Contradictions can be inferred from different documents. For example, according to the DCDRSLM, land should not forcibly be acquired if the compensation does not meet the standard. In other words, the DCDRSLM does not permit forced land acquisition (Ministry of Land and Resources of the People's Republic of China, 2004). However, the AMLA states that the conflicts which resulted from compensation standards that are not compliant with the LAS will not influence its implementation, and therefore allow for forcible acquisition (Ministry of Land and Resources of the People's Republic of China, 2015). This kind of inconsistency has led to statutory documents full of loopholes, allowing local governments and village committees to implement policies that are favourable to them but unfavourable to villagers in practice. Such appears to be the case in Village $\mathrm{C}$.

In accordance with the AMLA, local governments are responsible for handling conflicts caused by compensation standards that are not compliant with the LAS (Ministry of Land and Resources of the People's Republic of China, 2015). If a local government is unable to handle that task, the relevant upper-level governments are then charged with the verdict. However, the Regulation on Complaint Letters and Visits (RCLV) stipulates that complaints being processed by any departments will not be accepted by upper-level governments for a 
prescribed period, and complaints to lower-level governments or staff will be forwarded to the relevant authority in the lower-departments (State Bureau for Letters and Calls, 2006). Yet, patently, it is unreasonable to ask a local government to handle issues created by some of its own questionable actions. In Village $\mathrm{C}$, some villagers sent letters to the complaint office in both central and provincial governments, alleging that local government and villager committee members behaved illegally. Their complaints were reportedly ignored.

\section{Unclear governance}

In land acquisition, the IICRLA requires that local land bureaus collaborate with agricultural and civil departments to supervise the distribution and the usage of monetary compensation and relocation among rural collectives (Ministry of Land and Resources of the People's Republic of China, 2005a). Land bureaus at each level consider if the implementation of LAS is legally permitted. The DCDRSLM lays down similar regulations, but the responsibility has been shifted to agricultural and civil departments. The AMLA states that local land bureaus have the right to request that a local rural collective provides a payment list and notifies villagers; local land bureaus also accept enquiries and reports about land acquisition information; the local and upper-level governments are responsible for handling conflicts (Ministry of Land and Resources of the People's Republic of China, 2015).

Thus, three differing bodies are given responsibility in the aforementioned documents which will invariably lead to no actor taking charge of the responsibility of supervision. There exists no consequence if any of the actors fails to perform his or her duties and the obscurities of the official documents have the potential to lead to dereliction of duty and more risky, illegal actions. Similar obscurity exists in documents concerning resettling landless farmers and insuring their livelihoods.

\section{Unlimited delegation to the village secretary}

The village secretary is the leader of the Chinese Communist Party (CCP) in any given village and is nominated for the role by an upper-level party committee and elected by the CCP villagers in the village. The unique rural administration pattern has provided the village secretary with great power and a wide range of responsibilities (O'Brien \& Li, 1999). The 
local government has the responsibility to direct the village committee's work but cannot intervene in any affairs within the scope of rural autonomy as the village committee does not belong to a government at any level (The Central People's Government of the People's Republic of China, 2010).

In Village $\mathrm{C}$, the village secretary exercised decision-making and power over land acquisition procedures. The local government appears to have allowed him both to co-opt public assets and arrest dissatisfied villagers. For example, interview participants stated that the money left over from the insufficient compensation for both the villagers' farmland and residential land were taken by the village secretary, and more apartments were allocated to the village secretary.

In Village $\mathrm{C}$, the village secretary has been in the position for 20 years and his father and grandfather were also the village's secretaries. Zhou (2004) argues that the reason corruption proliferates in such organisations is that the high costs involved in securing information makes it difficult for farmers to get up-to-date and useful information and protect their rights. As villagers have no independent economic power or political rights, they are incapable of counterbalancing the concentrated and centralised rights of officials. Thus, the administrative rights of the village committee easily turn to prerogative. For example, and again according to interview participants, households with close relationships to the village secretary were allocated more apartments and more rent compensation annually. In return for these, villagers who were more highly compensated monitored and reported to the secretary the identity of those who were dissatisfied with the land acquisition and what actions they may be planning on taking.

\section{Cumulative effects of inappropriate procedures and the power of the village secretary}

The combination of unclear land acquisition procedures and the power of the village secretary in Village $\mathrm{C}$ has meant that the local government and village committee are able to change de jure procedures in de facto ways to benefit themselves. In this land acquisition case, a local government appears to have hidden land acquisition information from its villagers; measured farmland in secret; and eventually told villagers about land acquisition when it was all but unavoidable. Then, although villagers realised that they had the right to apply for a 
public hearing to voice their opinions on the land acquisition and compensation standard, it was too late to lodge an application. From the perspectives of the local government and village committee, informing the villagers at the correct time may damage their interests and increase their workloads.

Ambiguous land acquisition procedures have also led to confusion about the legal aspects of land acquisition amongst the villagers. As results, villagers made three miscalculations in their visit to the local government after farmland acquisition was announced, which then resulted in more serious repercussions. First, their visit did not start from the lowest organisation of village committee. Second, the number of people who made the visit exceeded the maximum of five as stated by the RCLV (State Bureau for Letters and Calls, 2006). Third, villagers blocked the gates of the local government building, which can be conceived as interfering with a government agency and disturbing the public order. The villagers believed this strategy was the best way to seek the local government's help, but with more legal knowledge they might have considered more official bargaining strategies. They might, for example, have requested proper documents, applied for a public hearing, and requested changes to the APCLU and LAS, which, in turn, may have led to fewer arrests and less violence-as the villagers stated in interviews. On the other hand, the villagers' protests were much later than they should have been. Better knowledge of the procedure could have allowed for more effective action against the improper land acquisition.

The land acquisition process in Village $\mathrm{C}$ suggests to us that local officials may have deliberately distorted official procedures and created very different de facto procedures and selectively implemented policies to produce results more favourable to them and at a cost to the public interest (Cai, 2004; see also Smith, 2009). The village secretary appears to have benefitted the most from the land acquisition and, at the same time, individual farmers' interests and rights appear to have been significantly eroded.

Finally, this research opens up questions for future work on land acquisition in China. Yet, the current anti-corruption campaign in China may not result in any fundamental changes to corruption because village secretaries are not government officials and therefore not subject to scrutiny during the campaign. Therefore, normalising land administration, abiding by de jure land acquisition procedures, eliminating ambiguity in policy implementation, and 
monitoring village head's actions should be carefully considered as means to improve the processes and procedures of future land sales and acquisitions in China.

\section{References}

Asif, M., 1999. Land Acquisition Act: Need for an alternative paradigm. Economic and Political Weekly, 34(25), pp.1564-1566.

Cai, Y., 2004. Irresponsible state: local cadres and image-building in China. Journal of Communist Studies and Transition Politics, 20(4), pp.20-41.

Cao, G., Feng, C. and Tao, R., 2008. Local "land finance" in China's urban expansion: challenges and solutions. China \& World Economy, 16(2), pp.19-30.

Ding, C., 2007. Policy and praxis of land acquisition in China. Land use policy, 24(1), pp.113.

He, S. and Wu, F., 2009. China's emerging neoliberal urbanism: perspectives from urban redevelopment. Antipode, 41(2), pp.282-304.

Hui, E. and Bao, H., 2013. The logic behind conflicts in land acquisitions in contemporary China: A framework based upon game theory. Land Use Policy, 30(1), pp.373-380.

Hui, E., Wu, Y., Deng, L. and Zheng, B., 2015. Analysis on coupling relationship of urban scale and intensive use of land in China. Cities, 42(A), pp.63-69.

Jining municipal government, 2009. Advice on Enhancing Management of Urban Housing Demolition. Available at: http://xxgk.jining.gov.cn/xxgk/jcms_files/jcms1/web2/site/art/2012/12/28/art_241_18 00.html [Accessed 8.9 2016].

Li, C., Wand, M. and Song, Y., 2018. Vulnerability and livelihood restoration of landless households after land acquisition: Evidence from peri-urban China. Habitat International, 79, pp.109-115.

Li, H., Huang, X., Kwan, M., Bao, H. and JEFFERSON, S., 2015. Changes in farmers' welfare from land requisition in the process of rapid urbanization. Land Use Policy, 42, pp.635-641.

Li, H., Wei, Y. and Zhou, Y., 2017. Spatiotemporal analysis of land development in transitional China. Habitat International, 67, pp.79-95. 
Li, L., Chen, X., Wang, Z. and Yang, H., 2006. Game analysis under incomplete information on behaviors of all stakeholders relating to land acquisition of large infrastructure project in China. 2006 IEEE International Conference on Management of Innovation and Technology, pp.221-224.

Lin, G. and Zhang, A., 2014. Emerging spaces of neoliberal urbanism in China: Land commodification, municipal finance and local economic growth in prefecture-level cities. Urban studies, 52(15), pp.2774-2789..

Liu, Z. and Liang, M., 2015. Study on Dual-Track System of Chinese Land Ownership. Cross-Cultural Communication, 11(9), pp24-28.

Matland, R., 1995. Synthesizing the implementation literature: The ambiguity-conflict model of policy implementation. Journal of public administration research and theory, 5(2), pp.145-174.

Ministry of Land and Resources of the People's Republic of China. 2003. Available at: http://www.mlr.gov.cn/pub/mlr/documents/t20040625_83923.htm. [Accessed 8.9 2016].

Ministry of Land and Resources of the People's Republic of China. 2004. Available at: http://www.mlr.gov.cn/zwgk/flfg/tdglflfg/200601/t20060112_642080.htm. [Accessed $8.92016]$.

Ministry of Land and Resources of the People's Republic of China. 2005a. Available at: http://www.mlr.gov.cn/zwgk/flfg/tdglflfg/200506/t20050617_68344.htm. [Accessed $8.92016]$.

Ministry of Land and Resources of the People's Republic of China. 2005b. Land Administration Law, the People's Republic of China. Available at: http://www.mlr.gov.cn/zwgk/flfg/tdglflfg/200506/t20050607_68174.htm. [Accessed 8.9 2016].

Ministry of Land and Resources of the People's Republic of China. 2006. Available at: http://www.mlr.gov.cn/zwgk/zytz/200701/t20070123_79059.htm. [Accessed 8.9 2016].

This article is protected by copyright. All rights reserved. 
Ministry of Land and Resources of the People's Republic of China. 2015. Available at: http://www.mlr.gov.cn/xwdt/mtsy/xinhuanet/201505/t20150522_1351443.htm. [Accessed 8.9 2016].

Ministry of Land and Resources of the People's Republic of China. 2017. Available at: http://www.mlr.gov.cn/xwdt/jrxw/201705/t20170504_1506781.htm. [Accessed 20.1 2019].

National Development and Reform Committee. 2016. Introduction of National Economic and Social Development Five-Year Plan. Available at: http://tgs.ndrc.gov.cn/ggzs/200511/t20051111_49686.html. [Accessed 8.9 2016].

O’brien, K. and Li, L. 1999., Selective policy implementation in rural China. Comparative Politics, 31(2), pp.167-186.

Ong, L., 2014. State-led urbanization in China: skyscrapers, land revenue and "concentrated villages". The China Quarterly, 217, pp.162-179.

Rooij, B., 2007. The return of the landlord: Chinese land acquisition conflicts as illustrated by peri-urban Kunming. The Journal of Legal Pluralism and Unofficial Law, 39(55), pp.211-244.

Shan, L., Yu, A. and Wu, Y. 2017., Strategies for risk management in urban-rural conflict: Two case studies of land acquisition in urbanising China. Habitat International, 59, pp.90-100.

Shandong Province Finance Bureau. 2015. Reply from Shandong Provincial Price Bureau and Financial Department Regarding Modulating Compensation Standard of Annual Production and Attachments for Acquiring Land. Available at: http://www.sdcz.gov.cn/modules/sdczww/resource/article/2015/09/15/9613.html. [Accessed 8.9 2016].

Shen, J. and Wu, F., 2016. The suburb as a space of capital accumulation: the development of new towns in Shanghai, China. Antipode, 49(3), pp.761-780.

Smith, G., 2009. Political machinations in a rural county. The China Journal, 62(Jul., 2009), pp.29-59. 
Song, Y., Wang, M. and Lei, X., 2016. Following the Money: Corruption, Conflict, and the Winners and Losers of Suburban Land Acquisition in China. Geographical Research, 54(1), pp.86-102.

State Bureau for Letters and Calls. 2006. Decree of the State Council of the People's Republic of China. Available at: http://www.gjxfj.gov.cn/200603/07/content_6399309.htm. [Accessed 8.9 2016].

Tang, S., Hao, P. and Huang, X., 2016. Land conversion and urban settlement intentions of the rural population in China: A case study of suburban Nanjing. Habitat International, 51, pp.149-158.

The Central People's Government of the People's Republic of China. 2004. Decision Concerning Deepening the Reform of Strict Land Management. Available at: http://www.gov.cn/gongbao/content/2004/content_63043.htm. [Accessed 19.1 2019].

The Central People's Government of the People's Republic of China. 2008. National Land Use Master Plan 2006-2020. Available at: http://www.gov.cn/zxft/ft149/content_1144625_2.htm. [Accessed 8.9 2016].

The Central People's Government of the People's Republic of China. 2010. Organisation Law of Villager Committee of the People's Republic of China. Available at: http://www.gov.cn/flfg/2010-10/28/content_1732986.htm. [Accessed 7.9 2016].

Wang, Y. and Hui, E., 2017. Are local governments maximizing land revenue? Evidence from China. China Economic Review, 43, pp.196-215.

Wang, Y., Liu, Y., Li, Y. and Li, T., 2016. The spatio-temporal patterns of urban-rural development transformation in China since 1990. Habitat International, 53, pp.178187.

Wen, L., Butsic, V., Stapp, J. and Zhang, A., 2017. Can China's land coupon program activate rural assets? An empirical investigation of program characteristics and results of Chongqing. Habitat International, 59, pp.80-89.

Yang, H. and Li, X., 2000. Cultivated land and food supply in China. Land use policy, 17(2), pp.73-88.

Zhou, Q., 2004. Ownership of farmland and institution of land acquisition. jingjixue jikan (China EconomicQuarterly), 4(1), pp.193-210 (in Chinese). 
Zhou, W., Peng, Y. and Bao, H. 2017., Regular pattern of judicial decision on land acquisition and resettlement: An investigation on Zhejiang's 901 administrative litigation cases. Habitat International, 63, pp.79-88.

Zhu, K. \& Prosterman, R., 2007. Securing land rights for Chinese farmers: A leap forward for stability and growth. Cato Development Policy Analysis Series, 3. 


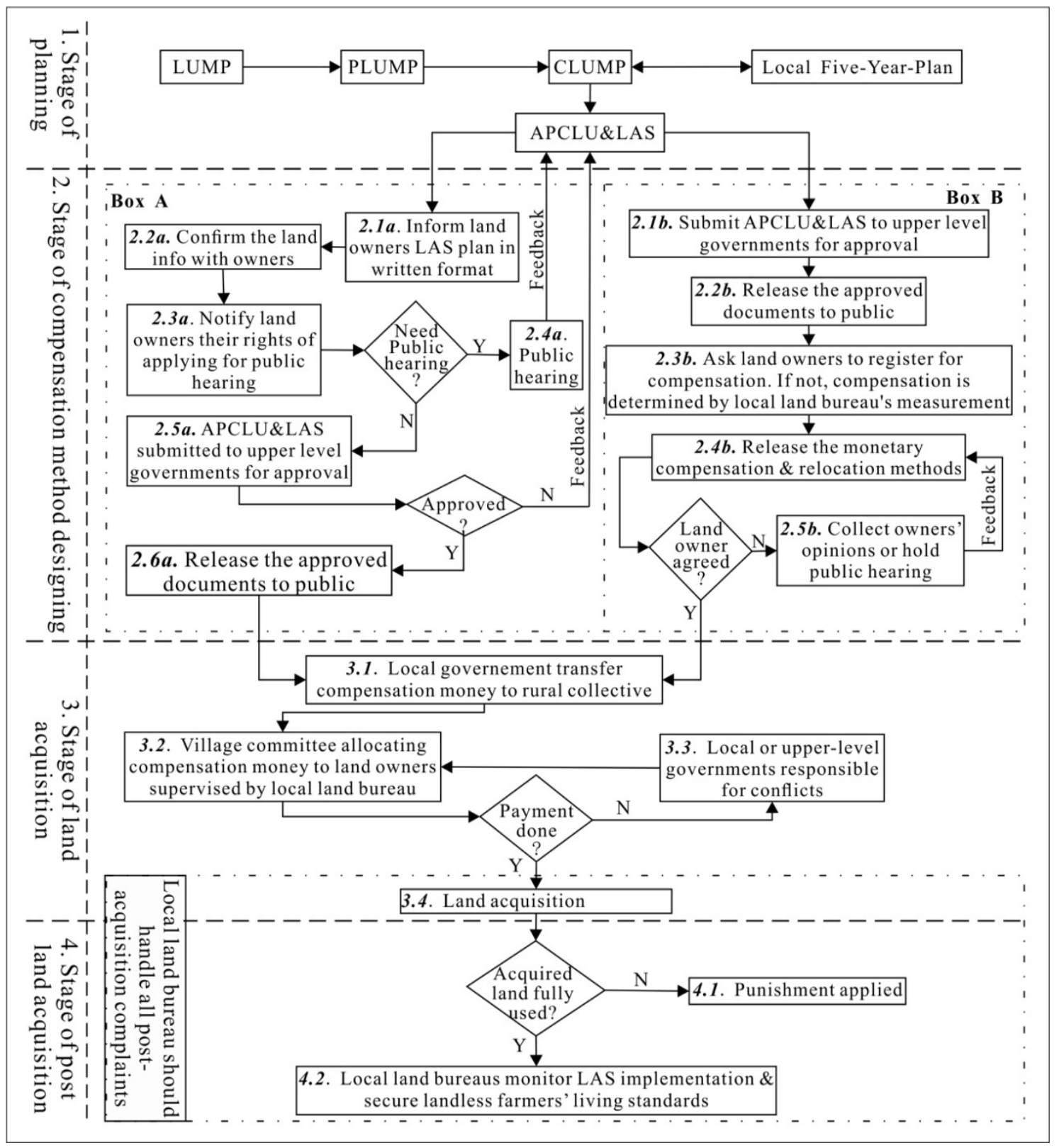

Figure 1. De Jure procedure of Land acquisition in Jining City, Shandong province, China

Note: LUMP: Land Use Master Plan; PLUMP: Provincial Land Use Master Plan; CLUMP: City Land Use Master Plan; APCLU: Annual Plan for City Land Use; and LAS: Land Acquisition Scheme 


\section{University Library}

\section{- M M N E R VA A gateway to Melbourne's research publications}

Minerva Access is the Institutional Repository of The University of Melbourne

Author/s:

Wang, MYL;Song, Y;Li, C

Title:

Land acquisition induced conflicts in suburban China: a procedural perspective

Date:

2019-08-01

Citation:

Wang, M. Y. L., Song, Y. \& Li, C. (2019). Land acquisition induced conflicts in suburban China: a procedural perspective. GEOGRAPHICAL RESEARCH, 57 (3), pp.275-285. https:// doi.org/10.1111/1745-5871.12343.

Persistent Link:

http://hdl.handle.net/11343/286865 